\title{
PUBLIC GOODS AND CRIMINALISATION
}

\author{
James Slater
}

\section{INTRODUCTION}

Theories of criminalisation seek to identify the criteria by which behaviour is legitimately criminalised. This article believes that their success in so doing is best assessed if they examine the question of criminalisation in light of four desirable features for any such theory. These desirable features, which this article will term desiderata for short, are as follows:

- Desideratum 1: a theory of criminalisation should offer an evaluative framework that justifies the form of legal regulation known as the criminal law.

- Desideratum 2: a theory of criminalisation's evaluative framework under Desideratum 1 should allow for a coherent and defensible account of the criminal law as morally censorious, thereby articulating something distinctive about the criminal law as a form of legal regulation.

- Desideratum 3: a theory of criminalisation should display a coherent understanding of how its evaluative framework under Desideratum 1 integrates with a theoretical account of the purpose, and legitimacy, of the state.

- Desideratum 4: a theory of criminalisation's evaluative framework under Desideratum 1 should distil criminal from non-criminal behaviour in a principled and defensible way.

Given that the defence of each desideratum would arguably generate an article apiece, the aims of this article are consequently more modest. It is aimed at those who already accept one or more of them. It will demonstrate the success, in satisfying the desiderata, of a theory of criminalisation embedded in the notion of public goods. It shall call this theory the public goods account (the 'PGA'). The PGA is not an entirely

\footnotetext{
* Senior Lecturer in Law, University of Buckingham. I am very grateful to John Gardner, bob Watt, March Stauch, Natalie Pratt and Sarah Sargent for their comments on earlier drafts of this article. The usual disclaimer applies.
} 
new theory, as elements of it can be found in the writings of a number of theorists. ${ }^{1}$ However, by expanding on, exploring and assessing these elements in light of the desiderata, this article offers further support to a theory of criminal law embedded in the notion of public goods.

In order to understand the PGA, it is necessary to begin this article with a section outlining the nature of public goods. Subsequent sections will then address how the PGA satisfies each desideratum, in the order they are set out above.

\section{THE NATURE OF PUBLIC GOODS}

In order to understand the nature of public goods, it is first necessary to understand the nature of a good. A good is a defined instance of the exercise of valuable autonomy that manifests itself in a particular moral, political, social or economic context. ${ }^{2}$ Individual goods are those when only one person exercises the relevant form of valuable autonomy: examples include eating and sleeping. Shared goods are when the exercise of valuable autonomy requires two or more people to cooperate: team sports and many forms of sexual activity are examples. Finally, an important feature of goods is that their autonomy component requires that the good be freely chosen.

Turning attention to the concept of a public good, Joseph Raz has provided the following definition:

[A good] that refers not to the sum of the good of individuals but to those goods which, in a certain community, serve the interest of

\footnotetext{
${ }^{1}$ See, for example: J Horder, Ashworth's Principles of Criminal Law (8th edn, OUP 2016) Chapter 3 'Criminal Law Values' and 'Bribery as a Form of Criminal Wrongdoing' (2011) 127 LQR 37; J Gardner and S Shute, 'The Wrongness of Rape' in Jeremy Horder (ed), Oxford Essays in Jurisprudence: Fourth Series (OUP 1998); reprinted with minor changes in Gardner, Offences and Defences: Selected Essays in the Philosophy of the Criminal Law (OUP 2007) 1, 31; AP Simester and A von Hirsch, Crimes, Harms, and Wrongs: On the Principles of Criminalisation (Hart Publishing 2011) 42-43.

2 As such they may require social forms to exist, see $\mathrm{J}$ Raz, The Morality of Freedom (Clarendon Press 1986) 309-312. See also Raz, Ethics in the Public Domain: Essays in the Morality of Law and Politics (Clarendon Press 1994) 121. This is the notion of valuable autonomy being dependent on social forms that give that autonomy meaning. For reasons of space, this claim cannot be interrogated here.
} 


\section{PUBLIC GOODS AND CRIMINALISATION}

people generally in a conflict-free, non-exclusive, and nonexcludable way. ${ }^{3}$

As Raz states, public goods possess the following characteristics: noncompetitiveness, that is to say that one person's enjoyment of the public good does not diminish that of others, though different persons will benefit to a different degree, and non-excludability, that is to say the public good is available to all, and benefits all, without exclusion. ${ }^{4}$ Thus, for example, the systematic provision of clean air is a public good, as the benefits of clean air are then enjoyed by all, and one person enjoying the fruits of clean air does not diminish its availability to others. ${ }^{5}$

Having outlined the nature of, on the one hand, individual and shared goods and, on the other, public goods, the connection between them can now be articulated: public goods are constituted by the non-exclusive and non-competitive availability, in any given society, of a range of individual and shared goods. ${ }^{6}$ In other words, the ability to exercise the valuable autonomy of the relevant individual or shared goods is enjoyed by all citizens, that is to say non-rivalrously and without discrimination. ${ }^{7}$

${ }^{3}$ Raz, Ethics in the Public Domain: Essays in the Morality of Law and Politics ibid 52-55, where Raz sets out his theory of public goods. Raz also uses the terms "common" and "general" good. See also 122, where Raz states that "... the conditions of autonomy ... depend on the common good, that is, on a good which if available to one is available to all and whose benefits can be had by all without competition or conflict." See also George Klosko, 'The Principle of Fairness and Political Obligation' (1987) 7 Ethics 353.

4 Klosko, ibid 353-354; Klosko notes: "[public goods] cannot be enjoyed by particular individuals without being made available to a much wider group of people, frequently to all members of the community." Klosko therefore implicitly accepts, correctly in the view of this article, that there may be (a few) legitimate exclusions from public goods. These include the exclusion of children from the franchise and the legal right to enter contracts. Such exclusions must, nevertheless, be carefully justified. Perfectionist liberals, such as Raz, might do so for reasons different to those committed to impartial liberalism.

${ }^{5}$ Raz, 'Rights and Politics' (1995) 71 Indiana Law Journal 27, 35.

${ }^{6}$ Ibid 37: "an adequate range of goods in society is a common good."

7 Public goods may well be politically controversial: see Raz, "Rights and Politics' (n 5) 38. Iseult Honohan also points out, correctly, that the language of common goods can mask political agendas, which suggests the need for political scrutiny: see her Civic Republicanism (Routledge 2002) 157. This article accepts that rights-based, and public reason type, arguments may be needed to nuance and supplement the provision of public goods; for example, the common good of a democratic polity benefits all, but, whilst foreign nationals might be legitimately excluded from the franchise, exclusions based on race are illegitimate. In this regard, see Horder, Ashworth's Principles of Criminal Law (n 1) 49. 


\section{THE DENNING LAW JOURNAL}

A distinction should be drawn at this stage between, on the one hand, those public goods that are concerned with a single good and, on the other, those goods that embrace a wider variety of goods, termed framing goods by Raz. ${ }^{8}$ Public goods concerned with a single good universally provide a range of individual and shared goods based on that good and that good only. Sexual integrity is an example: it is constituted by the systematic availability of a sufficient range of the private and shared goods involving sex. Another example is a democratic polity, which provides the individual and shared goods that make up a citizen's democratic identity, not least the individual good of the right to vote. By way of contrast, Raz has defined framing goods as those '...goods the existence of which is a precondition for the existence of an adequate range of other goods in the society. ${ }^{, 9}$ Framing goods include the public peace, which provides for the many different kinds of private and shared goods that are themselves dependent on physical and psychic autonomy. The public purse is also a framing good: it provides general sustenance for valuable autonomy, by financing all the institutions of the state that contribute to the valuable autonomy of its citizens. Another example of a framing good is a clean environment, which provides a general enabling environment for a significant range of individual and shared goods.

Public goods can be positive or negative. ${ }^{10}$ They are positive when their existence involves the creation, often at public expense, of a supportive environment for the exercise of valuable autonomy, such as green spaces, secondary education and a democratic polity. They are negative when they constitute protection from interferences with autonomy, such as a culture of tolerance, the public peace and freedom of expression.

The fact that public goods provide for the systematic protection of individual and shared goods might lead some to think that public goods have no intrinsic value, but are merely instruments in the provision of individual and shared goods. There are two reasons why this is not so, and it will emerge in this article that these two reasons are central to the PGA's conception of the nature, justification and limits of the criminal law.

First, public goods have intrinsic value because of their characteristics as non-excludable and non-rivalrous. This characteristic means that public goods instantiate the notion of making the relevant private and shared goods available to all. It is therefore in the nature of public goods that all

\footnotetext{
${ }^{8}$ Raz, 'Rights and Politics' (n 5).

${ }^{9}$ Ibid.

${ }^{10}$ As pointed out by Horder, 'Bribery as a Form of Criminal Wrongdoing' (n 1) 44-45.
} 


\section{PUBLIC GOODS AND CRIMINALISATION}

citizens should enjoy the various forms of valuable autonomy made available by public goods; consequently, they reflect a fundamental commitment to the equality of citizens where the exercise of valuable autonomy is concerned. Second, public goods have intrinsic value because their contribution to valuable autonomy often transcends the sum of individual valuable autonomy they provide and protect. The framing goods of the property regime and a democratic polity illustrate this capacity.

The property regime defines and protects those private and shared goods required to create the regime, including the shared good of contract. However, the economic benefits of the property regime, not least its wealth creating capacity, and the opportunities those economic benefits create, for example through taxation, transcend the sum of individual good each participant derives from the private and shared goods protected by the regime. And it is a significant reason why we value the public good of the property regime that it possesses these overarching benefits.

In the same vein, a democratic polity protects those individual and shared goods required to create democratic government, including the individual good of the right to vote. However, a democratic polity also provides a range of benefits that transcend the sum of individual interests it protects. For example, it ensures the continued responsiveness of government to the wishes of the people and maintains, through inter-party competition, the quality of political debate. Thus the quality of the political environment is also a concern of a democratic polity, a concern that, once successfully realised, benefits all citizens. ${ }^{11}$

The above two examples reveal that public goods are valuable not only because they provide valuable options to all citizens; they are also valuable because, by increasing the impact, benefits and consequences of the exercise of valuable autonomy, they enhance the value and effect of those options. Public goods are greater than the sum of their parts. This overarching quality is evidenced by the fact that both the above public goods benefit those who are too young to enter contracts or vote, i.e. are ineligible, for legitimate reasons, to exercise the valuable autonomy provided by the relevant individual and shared goods. ${ }^{12}$ It also explains the inalienability of the right to vote, since the systematic selling of that

\footnotetext{
11 This is the quality of dual harmony: see Raz (n 46) and accompanying text in this article.

12 The point concerning children benefiting from the property regime is taken from Raz: see Ethics in the Public Domain (n 3) 53-54. On the question of legitimate exclusions, see (n 4) and (n 7).
} 
right would undermine the distinctive benefits provided by the public good of democratic government. ${ }^{13}$

Having expanded on the nature of public goods, attention can now turn to how the PGA satisfies the desiderata.

\section{THE PGA AND DESIDERATUM 1}

Desideratum 1 ('D1') states that a theory of criminalisation should offer an evaluative framework that justifies the form of legal regulation known as the criminal law. Its reference to an evaluative framework incorporates explanatory, justificatory and critical strands. By explanatory, it means a theory of criminalisation must set out its criteria for the criminalisation of behaviour. By justificatory, it means a theory of criminalisation must defend those criteria in light of moral and/or political values. In other words, why is the criminal law, as that theory conceives it, a good thing? Finally, by critical, a theory of criminalisation should suggest reform and improvement to existing systems of criminal law, whilst possessing a measure of descriptive accuracy where such systems are concerned. ${ }^{14}$ For reasons of space, and because the critical strand of a theory of criminalisation flows from its explanatory and justificatory strands, this article will focus on the explanatory and justificatory strands.

\subsection{The explanatory strand of D1}

The PGA is a theory of criminalisation that shares with certain theories of criminalisation the notion that wrongfulness, conceived of in some way, is an intentional object of criminalisation. And so, in this section, the article will set out the PGA's criteria of criminal wrongfulness. Before proceeding, however, it is necessary to expand somewhat on the familiar distinction between crimes that are mala in se and those that are mala prohibita. Admittedly, the nature of this distinction, or even the fact of making it, is controversial. The reason for

13 This point concerning the inalienability of the right to vote and the public good of a democratic polity is taken from Raz, 'Rights and Politics' (n 5) 34.

${ }^{14}$ The need for theories of criminalisation to have both descriptive and normative dimensions has been summarised by R Dagger: see his 'Republicanism and the Foundations of Criminal Law' in RA Duff and SP Green (eds), Philosophical Foundations of Criminal Law (OUP 2011) 44, 45, where he states that such theories "... must account for the leading features of the criminal law and point the way to its reform or further development." It should be noted that there is a risk of a significant gap between, on the one hand, theories of criminalisation and their account of the rules and principles of the criminal law and, on the other, the implementation of those rules and principles in actual practice. 


\section{PUBLIC GOODS AND CRIMINALISATION}

offering an explanation will become clear: the distinction, as this article conceives it, serves as a necessary backdrop to the PGA's account of criminalisation. ${ }^{15}$

Moral wrongs are determinations that certain behaviour should not be performed in light of the moral reasons for and against that behaviour in any given context. On occasion the wrongs that emerge from such determinations will admit of relatively little disagreement as to their form: it is the crimes that seek to reflect such wrongs that are mala in se. It is for this reason that, when they accurately reflect their source morality, mala in se crimes such as murder and rape take much the same form across jurisdictions. It is the precision of the source morality where such crimes are concerned that accounts for their conventional definition as wrongful independent of law: in such cases, the criminal law is, to a significant degree, simply a formally posited definition of what morality already articulates.

By way of contrast, mala prohibita crimes are concerned with those occasions when the morality from which the criminal wrong is derived is considerably more ambiguous. The reason for such ambiguity lies in the highly abstract nature of certain moral objectives, of which perhaps the most pervasive example is the objective to make the world a safer place. How abstract moral objectives of this nature are particularised in the context of complex projects of social and economic coordination admits of enormous variety in matters of detail. For this reason, a number of different definitions of any derivative criminal wrong will do justice to the source morality. Yet the principle of maximum certainty in the criminal law requires that a line be drawn somewhere: where exactly may be somewhat arbitrary or governed by local contingencies. Because the line between what is and is not criminal therefore depends largely on what the law says, as opposed to being governed by fidelity to an underlying morality, what is prohibited remains 'unknown' until a definition is supplied by the criminal law. ${ }^{16}$ It is this fact that accounts for the conventional definition of mala prohibita crimes as wrong only because

\footnotetext{
${ }^{15}$ For an excellent exploration of the nature of this distinction, see the trilogy of papers (special topic) published in Dialogue: Canadian Philosophical Review (2016) 55 (1), as follows: S Dimock, 'A Trilogy of Papers on the Malum prohibitum-Malum in se Distinction in Criminal Law: Introduction' 1; S Dimock, 'The Malum prohibitum-Malum in se Distinction and the Wrongfulness Constraint on Criminalization' 9; SP Green, 'The Conceptual Utility of Malum prohibitum' 33; C Flanders, 'Public Wrongs and Public Reason' 45. See also Simester and von Hirsch, Crimes, Harms, and Wrongs: On the Principles of Criminalisation (n 1) 24-29.

${ }^{16}$ Or the criminal law in conjunction with the civil law.
} 


\section{THE DENNING LAW JOURNAL}

the law says so. Such crimes are therefore prohibita to the extent their final formulation could legitimately have taken different forms. However, they are mala to the extent that they do justice to their underlying moral objective. So no crime can be mala by dint of prohibition alone. ${ }^{17}$

It is important to note that this article conceives of the difference between mala in se and mala prohibita as one of degree, rather than one of kind. ${ }^{18}$ This is because even those criminal wrongs conventionally seen as reflecting mala in se admit of some measure of reasonable discretion in the exact form they take. This may be due to reasonable differences in conceptions of the underlying morality or it can flow, as will be argued later in the article, from how the criminal law puts its legitimate political goals into effect. ${ }^{19}$ For example, whether only certain, or alternatively all, frauds in the inducement are constitutive of the wrong of rape, is a controversy within morality. ${ }^{20}$ When the criminal law settles on which frauds in the inducement to include and exclude, and for what reasons (moral, political or a mixture of both), ${ }^{21}$ it is making a choice that accounts for a measure of prohibita where the crime of rape is concerned. What prohibita therefore means in the context of criminalisation is discretion as to form when, in light of the relevant source morality, a crime can take more than one legitimate form. ${ }^{22}$

17 As Simester and von Hirsch point out, the state cannot make something wrong simply by declaring it so: see Simester and von Hirsch, Crimes, Harms, and Wrongs: On the Principles of Criminalisation (n 1) 24-27.

18 This insight is taken from Green (n 15).

19 Duff makes a similar point: see his Punishment, Communication and Community (OUP 2001) 64-67.

${ }^{20}$ For a conception of rape that conceives of the wrong as a violation of selfpossession, as opposed to sexual autonomy, and the implications of this conception for the criminalisation of frauds in the inducement, see J Rubenfeld, 'The Riddle of Rape-by-Deception and the Myth of Sexual Autonomy' (2013) 122 Yale Law Journal 1372.

21 See the difference in opinion between Jonathan Herring and Hyman Gross played out in the following articles: Herring, 'Mistaken Sex' [2005] Crim LR 511, Gross, 'Rape, Moralism and Human Rights' [2007] Crim LR 220 and Herring, 'Human Rights and Rape: A Reply to Hyman Gross' (2007) Crim LR 228.

${ }^{22}$ It should be noted that, despite the fact that such lines can be reasonably drawn in different places where such crimes are concerned, their source morality means some places where those lines are drawn are, as Douglas Husak points out, indefensible: see his Overcriminalization: The Limits of the Criminal Law (OUP 2008) 110. See also Dimock 'Contractarian Criminal Law Theory and Mala Prohibita Offences' in Duff, L Farmer, SE Marshall, M Renzo and V Tadros (eds), Criminalisation: The Political Morality of the Criminal Law (OUP 2014) 


\section{PUBLIC GOODS AND CRIMINALISATION}

In light of the distinction between mala in se and mala prohibita crimes as outlined above, the explanation of how the PGA identifies criminal wrongs can begin with those crimes that most saliently embody a concern with public goods, those that, as Duff expresses it, "wrong or harm the polity as a whole, rather than a distinct identifiable individual. These include such serious crimes against collective, shared goods as treason and attempting to pervert the course of justice; tax evasion [and] "public nuisance". ${ }^{23}$ These crimes, which shall be termed public crimes for short, can be found at various points along the spectrum between mala in se and mala prohibita. According to the PGA, they are united by the fact that the criminal prohibition seeks to maintain one or more public goods, for example the environment, the public purse or health and safety.

For those public crimes closer to the mala prohibita end of the spectrum, wrongfulness is governed predominantly by the fact that the individual and/or systematic commission of the crime reduces the availability of the particular form(s) of valuable autonomy provided, directly or indirectly, by the public good(s) concerned. Such crimes are mala in se to the extent that they constitute reasonable and carefully considered attempts to target behaviour that directly or indirectly, in isolation or cumulatively, sets back the provision of the valuable autonomy. But they are largely prohibita because the manner in which autonomy is protected in particular contexts, for example food, drug or road safety, admits of much discretion. This category accounts for those crimes of a regulatory nature, often strict and met with milder punishment, that are designed, in a fairly instrumental way, to maintain autonomy in given contexts, such as health and safety and the transport system.

However, public goods are not exclusively concerned with the provision of autonomy per se: rather, they articulate and protect environments where the exercise of autonomy has moral value and significance. It is for this reason that they are characterised by a number of moral principles. For example, all public goods associated with the public good of the rule of law, such as the public purse and the systems of civil and criminal justice, are characterised by the notions of fairness, objectivity, honesty and integrity. In turn, for those public crimes closer to the mala in se end of the spectrum, the wrongfulness of the behaviour flows from the fact it violates the moral principles that characterise the

$151,175:$ ' ... not all ways of providing determinate content to mala in se wrongs are acceptable.'

${ }^{23}$ Duff, Answering for Crime: Responsibility and Liability in the Criminal Law (Hart Publishing 2007) 140. Duff is expressing this notion within the context of what it means for a wrong to be public, for the sake of his 'public wrong' account of criminalisation: see (n 52). 


\section{THE DENNING LAW JOURNAL}

public good and make the existence of the public good valuable. Alternatively, such mala in se crimes violate the moral principles that assist in the provision of the valuable autonomy characteristic of the public good.

Let us take, for example, public crimes that target tax evasion. Such crimes are designed to sustain the public purse. Of course, these are mala prohibita to the extent that their reach is dependent on the contingencies of how the targets, and levels, of taxation are decided within any given jurisdiction. But the public purse is more than simply the methodological notion of money gathered through taxes: it is characterised by a number of moral principles. These include fairness in distribution and the presence of honesty and integrity in those public officials tasked with gathering and spending the sums raised through taxation; the latter requires that tax is gathered for, and spent on, the business of government, not syphoned away for personal advantage. Offences that are designed to maintain the public purse will therefore be mala in se to the extent that they constitute violations of these moral principles. For example, when the burden of taxation is justly distributed, tax evasion is rightly characterised as wrongful, as a form of cheating and free riding. In the same vein, some instances of the electoral offence of personation, that is voting as another person, violate the democratic principle of 'one-person, one vote', which is itself derived from the principle of political equality. ${ }^{24}$ Thus the wrongfulness of (some forms of) personation is constituted by the violation of important values that constitute the public good of a democratic polity.

However, as will be defended in greater detail in the next subsection, what completes the case for the criminalisation of these more mala in se public crimes, as well as their more mala prohibita cousins, is the damaging impact their systematic commission would have on the various forms of valuable autonomy provided by the relevant public good. This impact can take different forms. Where positive public goods are concerned, it may take the form of a reduction in the means by which the state creates a supportive environment for valuable autonomy. For example, though a single instance of tax evasion may have no practical effect on the public purse in its capacity as a framing good, systematic tax evasion does. This is because the consequent loss of funds to the state will reduce its capacity to provide numerous public goods, such as the public

\footnotetext{
24 For a defence of this argument, see J Slater and b Watt, 'In Defence of Democracy: The Criminalization of Impersonation' (2015) 14(2) Election Law Journal: Rules, Politics, and Policy 165.
} 


\section{PUBLIC GOODS AND CRIMINALISATION}

peace and secondary education. ${ }^{25}$ Alternatively, systematic commission of the offence may undermine the overarching benefits of a public good, thereby eroding the valuable nature of the autonomy it provides. To illustrate, though a single instance of personation may not alter an election result, systematic personation will eventually erode the provision of the valuable autonomy characteristic of a democratic polity. It will do so principally by undermining the overarching benefits of a democratic polity, such as the confidence of the electorate in the electoral system and the responsiveness of political parties, and government, to the wishes of the people. ${ }^{26}$

On the other hand, the relationship between public goods and mala in se crimes such as murder, theft and rape, which are wrongs against individuals as opposed to the public, seems less obvious. The PGA's concern with public goods suggests the individual does not feature in the PGA's account of criminalisation, and, consequently, that it would struggle to give a satisfactory account of such crimes. The nature of this (potential) flaw is outlined by Duff:

If we are going to say that such actions as murder, rape and theft should be criminal because they injure or threaten some common good, are we not then ignoring, and thus denigrating, the wrong done to the individual victims of such actions-a wrong which surely should be central to the law's concerns? ${ }^{27}$

\footnotetext{
${ }^{25}$ Green points out that it is in the nature of tax evasion that it is 'significant only in aggregate': see his 'What is Wrong with Tax Evasion?' (2009) Houston Business and Tax Law Journal 220, 226.

26 See Slater and Watt, 'In Defence of Democracy: The Criminalisation of Impersonation' (n 24).

${ }^{27}$ Marshall and Duff, 'Criminalization and Sharing Wrongs' (1998) 11 Canadian Journal of Law and Jurisprudence 7, 12. Similarly in Answering for Crime (n 23) 141, Duff states: "If we ... argue that such mala in se as murder and rape count as public wrongs only because they too have a harmful or wrongful impact on 'the public', as well as on their individual victims, we are likely to distort the wrongfulness that makes them criminalisable. Even if a rapist takes unfair advantage over the law-abiding (which is at best arguable), or creates 'social volatility' or undermines trust, that is not what is central to the criminal wrongfulness of his action; what he is properly convicted and punished for is the wrong done to his victim." This point is a common theme in Duff's work: see, for example, Punishment Communication and Responsibility (n 19) 60 and Public and Private Wrongs (again with Marshall) in J Chalmers, F Leverick and Farmer (eds) Essays in Criminal Law in Honour of Sir Gerald Gordon (Vol 5 Edinburgh Studies in Law, Edinburgh University Press 2010) 71.
} 


\section{THE DENNING LAW JOURNAL}

As Duff explains further, the problem with accounts that exhibit an exclusive concern with the public, or common, good, is that they ...:

... seem to subordinate the individual victim (a concern for their good, or for the wrong done to them) to some supposedly larger social good. The offender's conduct is counted as criminal, and he is to be punished, for the sake of that larger good: to which it is appropriate to object that his conduct should be criminalised because of, and he should be punished for, the wrong he does to the individual victim. We do not criminalise rape, and punish rapists, because rape causes social volatility; or because the rapist takes an unfair advantage over his law-abiding fellow citizens: but because of the nature of the wrong that the rapist does to his victims. ${ }^{28}$

Duff is making two closely related claims here. First, he is suggesting that theories of criminalisation that justify the criminalisation of wrongs against individuals purely in terms of some benefit to the public, for example because they suppress social volatility, fall into error by ignoring the wrong done to the individual. ${ }^{29}$ Second, he is suggesting a theory's account of such crimes should be reacting, in some fairly fine-grained way, to the moral mala committed against the victim.

The position of this article is that the first claim is self-evidently true: some conception of what happens to the individual must play its part in the nature and justification of such crimes. In this section, the article will therefore demonstrate how the PGA does not suffer from this flaw. It will also address the second claim, by demonstrating how the PGA is sufficiently fine grained to respond appropriately to the moral mala experienced by the individual. In the next section, which addresses Desideratum 2, it will then defend the claim that this is what the criminal law should be doing, to the extent that a distinctive, that is to say

\footnotetext{
${ }^{28}$ Marshall and Duff, 'Criminalization and Sharing Wrongs' ibid.

${ }^{29}$ Duff's own 'public wrong' account of criminalisation does not fall foul of this error. This is because he fuses concern with the moral wrong done to the individual with the quality of publicness, by arguing that the moral values that define the behaviour as wrong where the individual is concerned are, simultaneously, part of the fabric of shared values that define the political community: see his 'Criminalization and Sharing Wrongs' (n 27) 20, where Duff states: “ ... wrongs against individual citizens can be understood as shared wrongs, as wrongs against the whole community, insofar as the individual goods which are attacked are goods in terms of which the community identifies and understands itself."
} 


\section{PUBLIC GOODS AND CRIMINALISATION}

censorious, account of the criminal law is not possible without so responding.

With regard to the first claim, the reason why the maintenance of public goods does not ignore the individual in the name of a distinct social goal is because creating and/or maintaining a public good frequently involves directly protecting the capacity of individual citizens to enjoy the valuable autonomy of various individual and shared goods. The public goods of the public peace and the property regime illustrate this.

The public peace is a public good because it assists all members of society in partaking in a wide range of individual and shared goods, by freeing them of physical interference and violence, and one member of society benefiting from the public peace does not diminish its availability to other members. ${ }^{30}$ However, it can only be provided by systematically protecting individual members of society from physical and psychic assault; in other words, it is through the protection of the individual goods of bodily and psychic integrity, in the form of fatal and non-fatal offences against the person, that the public good is created. The core of the criminal wrong therefore consists of the invasion of the valuable autonomy of the individual.

The property regime is a public good because it provides, for all citizens, “... opportunities for personal and social advancement through reliable coordinated economic activity, and for other forms of welfare and personal realisation that only the peaceful ownership and possession of property can deliver." ${ }^{31}$ The foundation of peaceful ownership and possession of property, along with its resulting benefits, is individual dominium over assets, with the nature of that individual dominium, and how it can be shared and exchanged, largely defined by the civil law. In turn, for the public good of the property regime to materialise, that system of individual dominium must also be protected. This is why the crime of theft, along with other property offences, target all those who seek to ignore or violate the rules of individual ownership, possession and transfer.

The above two examples reveal that, where certain public goods are concerned, there is a symbiotic relationship between, on the one hand, the systematic protection of the valuable autonomy of individuals and, on the other, the maintenance of the relevant public good. This symbiosis means that, where wrongs against individuals are concerned, the PGA conceives of the criminal law as possessing what Blackstone termed a 'double view': an interest in both protecting the individual's valuable autonomy

\footnotetext{
${ }^{30}$ Horder, 'Bribery as a Form of Criminal Wrongdoing' (n 1) 44.

31 See Simester and von Hirsch Crimes, Harms, and Wrongs: On the Principles of Criminalisation (n 1) 42.
} 


\section{THE DENNING LAW JOURNAL}

and protecting the public. ${ }^{32}$ It is this 'double view' that means the PGA does not ignore the individual in the name of a distinct public good, because concern with the valuable autonomy of the individual is the fundamental building block of the public good. The PGA then simply demands that that protection be offered systematically to all, such that a distinct, non-rivalrous and non-excludable good is created.

As for the nature of the wrong done to the individual, does the PGA have the capacity to articulate the moral mala experienced by the individual? The answer is yes and flows, as with public crimes, from the fact that public goods are characterised by a number of moral principles that mean the autonomy they foster and protect is valuable in nature.

For example, the public peace is more than the existence of freedom from physical and psychic attack. It concerned with the human dignity of each citizen and the public's conception of their security and social environment. This concern with human dignity means it is interested in marking the difference between, say, murder, a deliberate attack, and gross negligent manslaughter, a morally culpable failure to meet a standard of conduct. It also accounts, it is suggested, for offences against the person defined in part by racial or religious animus. These various wrongs threaten the public peace in different ways: proclaiming them as crimes, and prosecuting in their name, gives the public peace its value, its moral character. ${ }^{33}$

This moral articulacy is also illustrated by sexual offences. There is a public good in the form of sexual integrity, a general sphere of valuable autonomy made up of the universal availability of various forms of human flourishing constituted by private and shared goods involving sex. ${ }^{34}$ Craig has listed these various forms of flourishing as follows:

32 Commentaries on the Laws of England (Clarendon Press 1769) Book IV, Ch 1, 7: "Upon the whole we may observe that in taking cognizance of all wrongs, or unlawful acts, the law has a double view: viz. not only to redress the party injured ... but also to secure to the public the benefit of society, by preventing or punishing every breach and violation of those laws, which the sovereign power has thought proper to establish for the government and tranquillity of the whole." See also Book IV, Ch 1, 5: “ ... every public offence is also a private wrong, and somewhat more; it affects the individual, and it likewise affects the community."

${ }^{33}$ Where racial or religious animus is concerned, see, for example, the Crime and Disorder Act 1998, sections 29 and 32. Fair labelling is therefore not just a concern for the accused: because of the interest of all citizens in the relevant public good, it is a concern for all citizens.

34 The article will not address whether and, if so, in what ways, a good is dependent on existing social forms and, additionally, grounded in independent criteria of value: the aim here is more limited, which is simply to demonstrate how the notion of public goods has moral granularity. 


\section{PUBLIC GOODS AND CRIMINALISATION}

... not only ... freedom from violations of sexual integrity but also promoting and protecting the 'conditions for' sexual fulfilment, sexual diversity, sexual literacy, the safety necessary for sexual exploration, the freedom to say 'yes,' and the capacity to gain sexual benefit (whether that benefit be physical, emotional, financial or social). ${ }^{35}$

These forms of human flourishing are clearly dependent on autonomy per $s e$. But the various private and shared goods of sex listed above are also morally and socially meaningful, in other words valuable, and sexual offences target that value in many different ways. For example, if consensual sex is joyful or recreational or an expression of deep love and commitment, or all three at the same time, the horror and exploitative nature of rape negates these qualities in a particular way. This is worthy of discrete articulation by a conception of the criminal law that seeks to foster the public good of sexual integrity.

Finally, the PGA has significant explanatory and evaluative power where the concept of criminal recklessness is concerned. Though recklessness has a role as a determinant of culpability, the requirement that the risk taken is unjustified means it is also concerned with the boundary between criminal and non-criminal behaviour. Whether a risk is unjustified is a complex socio-moral, that is to say normative, judgment. It requires balancing the social utility of taking the risk against the gravity of the harm it might cause, as well as its likelihood to cause that harm, with a view to establishing whether the risk is worth taking. In other words, whether an activity is reckless depends on how that conclusion integrates with the promotion of valuable autonomy generally, the net gain in valuable autonomy from the toleration of risk. Because the raison d'etre of the PGA is the promotion valuable autonomy, rather than autonomy per se, it provides a normative context that engages directly with how those risks are assessed and tolerated.

\subsection{The justificatory strand of D1}

The justificatory strand of D1 is concerned with the question why the decision to criminalise behaviour is a good thing. The PGA sees this justification in the criminal law's impact on practical reason, with the result that citizens desist or are deterred from committing criminal wrongs, with a view to creating and/or maintaining public goods. This

${ }^{35}$ E Craig, Troubling Sex: Towards a Legal Theory of Sexual Integrity (UBC Press 2012) 136. 
justification of the criminal law is derived from Raz's conception of the purpose, and legitimacy, of the state. This purpose is to create, through law and other measures, the social conditions under which citizens can lead autonomous lives, through the provision of a sufficient range of individual and shared goods. The PGA's theory of criminalisation is therefore embedded in, rather than independent of, a political theory of the state. ${ }^{36}$ The reasons for criminalisation are fundamentally political in nature. The implications of this approach for the definitions of criminal wrongs and the rules of attribution will be examined in Section 5, when this article explores the implications of the PGA's political approach to the criminal law. This section will address why such an approach justifies the criminal law, as the PGA sees it.

The support for autonomy within this conception of the state's role is perfectionist in nature: this means that personal autonomy is worthy of state support only to the extent that it is exercised in favour of valuable options. ${ }^{37}$ Raz explains:

...the autonomy principle is a perfectionist principle. Autonomous life is valuable only if it is spent in the pursuit of acceptable and valuable projects and relationships. The autonomy principle permits and even requires governments to create morally valuable opportunities ... ${ }^{38}$

${ }^{36}$ For a discussion of the whether the starting points of a theory of criminalisation should be political or moral, see Duff et al, Criminalization: The Political Morality of the Criminal Law (n 22) 17-26.

${ }^{37}$ Raz, The Morality of Freedom (n 2) Ch 15, 'Freedom and Autonomy'. For a critical analysis of Raz's perfectionist liberalism, see P Neal, 'Perfectionism with a Liberal Face? Nervous Liberals and Raz's Political Theory' (1994) 20 Social Theory and Practice 25.

${ }^{38}$ Raz, The Morality of Freedom (n 2) 417; see also 133, where Raz states: “... it is the goal of all political action to enable individuals to pursue valid conceptions of the good ..." Raz also believes that the state is under a duty to discourage or eliminate empty or evil options, as these quotes go on to state. According to Raz, there are no barriers, in principle, preventing the state from targeting worthless options through coercion because, according to Raz, there is no value in autonomy per se (418). However, he acknowledges both pragmatic and contingent objections. The pragmatic objections consist of, first, the possibility of error, by government, as to what is valuable (427) and, second, the fact that the pursuit of too many perfectionist policies may lead to civil strife (429). The contingent objection is that coercion will have a collateral effect on the exercise of valuable autonomy (418-419). Contra Raz, this article believes that the coercive effect of the criminal law means it should be confined to promoting, and protecting, valuable autonomy, as matter of principle. Autonomy per se has sufficient value such that the criminal law cannot be used to suppress valueless 


\section{PUBLIC GOODS AND CRIMINALISATION}

Additionally, and equally importantly, the state's support of autonomy requires it to provide a wide range of individual and shared goods: it is only in the face of a sufficient range of valuable options that the pursuit of any given valuable option is freely chosen, that is to say autonomous. ${ }^{39}$ As explained above, the provision of public goods is fundamental to the state fulfilling this role because, as Raz states: "Public goods lie at the foundation of most options." ${ }^{40}$ And so, when the state provides a wide range of public goods, this ensures that all citizens have an adequate range of individual and shared goods to choose from, which also ensures that the goods are chosen freely. Public goods are therefore fundamental to the ability of citizens to lead autonomous lives.

According to the PGA, the criminal law is necessary for the creation and maintenance of public goods. This is because, echoing the concept of public goods in economic theory, the creation of public goods cannot be left exclusively to the 'market' of enforcement by aggrieved individuals pursuing private law remedies. Such enforcement would not occur systematically enough to create the system of deterrence necessary to bring public goods into existence. Market failure will result for a number of reasons: one is that victims often lack the resources required to mount a prosecution; another is that many crimes do not produce individual victims in any event. Accordingly, public goods need the systematic support from the state, in its capacity as police authority and prosecutor, to materialise. Of course, according such a purpose to the criminal law is subject to an efficacy condition, that the criminal law will, indeed, be effective as a deterrent.

However, just because autonomous lives cannot exist without the criminal law does not address a more fundamental question, which is whether the state is justified in using the form of regulation known as the criminal law, as the PGA conceives it, to achieve this objective? The

autonomy, though the state is under no duty to provide it, or protect it, through the criminal law, or other measures.

${ }^{39}$ Raz, The Morality of Freedom (n 2) 204, 408, 410, 417-18, 425. See also his Ethics in The Public Domain (n 3) 121, where he states: "One is autonomous only if one lives in an environment rich with possibilities."

${ }^{40}$ Raz, Ethics in the Public Domain (n 3) 121. See also The Morality of Freedom (n 2) 207: "The provision of many collective goods is constitutive of the very possibility of autonomy ...". 


\section{THE DENNING LAW JOURNAL}

answer is yes, because such a theory engages directly with, first, the state administered and, second, the coercive nature of the criminal law. ${ }^{41}$

With regard to the fact that the criminal law is a state created and administered practice, the criminal law is a resource intensive enterprise. ${ }^{42}$ The use of public resources requires a justification that speaks to the polity as a whole: the vindication of moral values, though a reason to criminalise, cannot justify, by itself, the expense and logistical efforts required to put the criminal law into effect. The PGA offers such a reason: the creation of valuable autonomy for all, via the means of public goods.

As for the question of coercion, the criminal law's transgression generates the risk of prosecution and punishment, including the possibility of incarceration. ${ }^{43}$ These risks create prudential, content independent reasons to comply that, on occasion, override the preferences of the individual concerned, and so are coercive in nature. For some, the bloodyminded and recalcitrant, such prudential reasons may be the only reasons for which they comply. ${ }^{44}$ Autonomy has sufficient value, even when exercised in the name of valueless options, that coercion requires justification. Furthermore, the impact on valuable autonomy of a conviction, for example its impact on reputation and employability, means the criminal law must, overall, have a positive effect on people's lives in order to be justified. ${ }^{45}$ According to the PGA, it is the maintenance of public goods, and the consequential beneficial impact such maintenance has on the valuable autonomy of all citizens, so that they may lead

${ }^{41}$ Simester and von Hirsch make similar point: see Crimes, Harms, and Wrongs (n 1) 118, repeated in 'On the Legitimate Objectives of Criminalisation' (2016) Criminal Law and Philosophy 367, 376.

${ }^{42}$ As noted by Matravers, 'Duff on Hard Treatment' in R Cruft, MH Kramer and MR Reiff, Crime, Punishment and Responsibility: The Jurisprudence of Antony Duff (OUP 2011) 68, 81.

${ }^{43}$ It should be noted that just because a theorist acknowledges that the criminal law is coercive does not mean that achieving that coercive effect need feature in the theorist's justification for the criminal law. For example, Michael Moore acknowledges that the criminal law is coercive but does not see preventing wrongdoing by coercion as justifying its existence. Rather, he argues its raison d'être is the imposition of punishment on those who deserve it: culpable moral wrongdoers; see Moore, 'Liberty's Constraints on What Should be Made Criminal' in Duff et al (eds), Criminalisation: The Political Morality of the Criminal Law (n 22) 182, 184.

${ }^{44}$ The expression "bloody minded and recalcitrant" is taken from Scott Anderson, 'Coercion' in the Stanford Encyclopedia of Philosophy <https://plato.stanford.edu/entries/coercion/> accessed July 2017.

${ }^{45}$ As noted by Simester and von Hirsch in Crimes, Harms, and Wrongs (n 1) 118 and 'On the Legitimate Objectives of Criminalisation' (n 41) 376. 


\section{PUBLIC GOODS AND CRIMINALISATION}

autonomous lives, that supplies a justification that engages directly with these facts.

It is also worth remembering the overarching benefits of public goods noted under Section 2, because such benefits are a key reason why public goods are valuable and thereby worthy of protection. In particular, these overarching benefits give rise to what Raz has termed the quality of dual harmony, whereby protecting the valuable autonomy of the individual creates the common good, and, in return, the common good, brings additional benefits to the individual. ${ }^{46}$ Raz explains dual harmony as follows:

...to the extent that the rightholder's interest is given extra weight for reasons of the common good, these reasons are not altogether detachable from considerations of the rightholder's own interest. The common good is the good of all, including the good of the rightholder. By serving the common good, the right also serves the interest of the rightholder in that common good. There is here what I have called elsewhere a dual harmony between the interest of the rightholder and the interest of other people which is served by his right. The right protects the common good by protecting his interest, and it protects his interest by protecting the common good. ${ }^{47}$

An example of dual harmony was touched upon in Section 2, when the overarching benefits of the public good of the property regime were described. The systematic protection of the individual and shared goods of ownership and contract creates the public good of the property regime, the existence of which, not least through its capacity for wealth creation, benefits the individual in return. It is this dual harmony of public goods that is also an integral part of justifying the expensive, autonomy impacting form of coercion known as the criminal law.

\section{THE PGA AND DESIDERATUM 2}

Desideratum 2 ('D2') means D1's evaluative framework includes a commitment to a coherent and defensible account of the criminal law as morally censorious. ${ }^{48}$ At the heart of D2 is the notion that the criminal law

\footnotetext{
${ }^{46}$ For an explanation of dual harmony, see Raz's Ethics in the Public Domain (n 3) 53-55.

${ }^{47}$ Raz, 'Rights and Politics' (n 5) 39.

${ }^{48}$ Of course, if a theorist rejects a distinct account of the criminal law, D2 is an irrelevancy.
} 


\section{THE DENNING LAW JOURNAL}

condemns the behaviour it criminalises: a theory's success in satisfying this desideratum will therefore depend on the coherence and defensibility of the condemnation it articulates. It also means the theory must not only condemn the wrong but also the wrongdoer: it should therefore have some conception of the moral culpability of those convicted of criminal wrongs. This means it should give an account of attribution. Attribution is concerned not with wrongdoing and justification, but rather with whether and how people are held to account for their (all things considered) wrongdoing. ${ }^{49}$ Amongst other things, it addresses the nature and reach of excusatory and exempting defences such as loss of control and insanity. ${ }^{50}$

A conception of the criminal law as condemning both wrong and wrongdoer offers a distinctive account of such law in two ways ${ }^{51}$ First, it seeks to distinguish the criminal law from those forms of legal regulation that are not censorious in nature, for example those associated with corrective justice, such as tort, or distributive justice, such as taxation. Second, and more crucially for the purposes of this article, it may be contrasted with non-distinctive accounts of the criminal law itself, which lack the element of moral censure.

The difference between distinctive accounts and non-distinctive ones is one of degree. At one end of the spectrum are purely distinctive accounts, which propose no other goal for the criminal law than the moral

49 John Gardner describes these elements of the criminal law as addressing "whether and how we should count what people have done when we are judging them." Gardner, 'Criminal Law and the Uses of Theory: A Reply to Laing' (1994) 14 OJLS 217, 220. See also Duff, 'Harms and Wrongs' (2001) 5 Buffalo Criminal Law Review 13, 19.

50 Thus, a theory of criminalisation embraces all those elements that govern the possibility, and nature, of conviction. This article agrees with Simester and von Hirsch that the grounds of criminalisation need not perfectly match those of punishment: see Crimes, Harms, and Wrongs: On the Principles of Criminalisation (n 1) 8. See also JR Edwards and Simester, 'Prevention with a Moral Voice' in A du Bois Pedain and U Neuman (eds) Liberal Criminal Law Theory: Essays for Andreas von Hirsch (Hart Publishing 2016) 43, 47: "There is no reason to think that the legitimate aims of criminalisation and punishment must be identical."

${ }^{51}$ For a summary of the nature of a distinctive account of the criminal law, see $\mathrm{M}$ Matravers, 'Political Neutrality and Punishment' (2013) 7 Criminal Law and Philosophy 217, 219-223. See also A Cornford 'Rethinking the Wrongness Constraint on Criminalisation' (2017) Law and Philosophy 1, 2-3 and P Pettit, 'Criminalization in Republican Theory' in Duff, Farmer, Marshall, Renzo and Tadros (eds), Criminalization: The Political Morality of the Criminal Law (n 22) $132,135$. 


\section{PUBLIC GOODS AND CRIMINALISATION}

condemnation of those who commit crimes. ${ }^{52}$ Such theories reject any deterrent and preventative role for the criminal law. ${ }^{53}$ At the other end of the spectrum, purely non-distinctive accounts reject concern with moral condemnation. Purely non-distinctive accounts are characterised by two aspirations: first, to conceive of the criminal wrong in as morally parsimonious fashion as possible, for example that behaviour is criminally wrongful simply because it is harmful or autonomy reducing; second, to see the criminal law is nothing more than a regulatory tool designed to reduce offending through the provision of prudential reasons to comply, in the form of fear of conviction and punishment. ${ }^{54}$ And some accounts find

52 The legal moralism of Moore and Duff are examples of purely distinctive accounts. For Moore, the purpose of the criminal law is to identify those who should receive 'deserved' punishment for moral wrongdoing: see his Placing Blame: A General Theory of the Criminal Law (OUP 1997) and 'Liberty's Constraints' (n 43). For Duff, the criminal law should be exclusively concerned with the communication of censure, both to the public at large and the criminal convicted, when public, as opposed to private, wrongs have been committed: "[W]e should not see the criminal law as prohibiting the conduct that it defines as mala in se-as offering the citizens content-independent reasons to refrain from such conduct. We should see it instead as declaring such conduct to constitute a public wrong properly condemned by the community, for which the agent is answerable to the community through a criminal process." See his Punishment, Communication and Community (OUP 2001) 64. This approach is a central pillar of Duff's conception of the criminal law: see, e.g., Answering for Crime (n 27) 84-93 and 'Responsibility, Citizenship, and Criminal Law' in Philosophical Foundations of Criminal Law (n 14) 125, 129. For an excellent summary of Duff's philosophy, see M Thorburn, 'Calling Antony Duff to Account' (2015) Criminal Law and Philosophy 737.

${ }^{53}$ Duff's rejection of deterrence flows from his commitment to the notion that the criminal law should display respect for persons, with the result that the provision of content independent reasons (the fear of sanction and punishment) is not a legitimate feature of the criminal law. Matravers has stated that Duff “... recoils at the slightest hint of deterrence": see 'Duff on Hard Treatment' in The Jurisprudence of Antony Duff ( $\mathrm{n}$ 42) 81. For an analysis of Duff's approach, see Matravers, Justice and Punishment: The Rationale of Coercion (OUP 2000) Ch 9, 'The Moral Community, Justified Coercion, and Punishment'. See also Thorburn, ibid 746.

${ }^{54}$ A purely non-distinctive account is that of Barbara Wootton: see her Crime and the Criminal Law: Reflections of a Magistrate and Social Scientist $\left(2^{\text {nd }}\right.$ revised edn, Steven \& Sons 1981). For a critique, see HLA Hart 'Review: Crime and the Criminal Law' (1965) 74 Yale Law Journal 1325. See also Matravers and Arina Cocoru 'Revisiting the Hart/Wootton Debate on Responsibility' in Christopher Pullman (ed), Hart on Responsibility (Palgrave Macmillan 2014). 


\section{THE DENNING LAW JOURNAL}

themselves somewhere in between these two extremes, mixing distinctive and non-distinctive elements. ${ }^{55}$

According to this article, the aspiration for a pure account is misplaced. Contra purely distinctive accounts, the notion that the criminal law has no preventative role, does not seek a forward-looking goal of reducing offending by impacting on the practical reason of potential offenders, ignores the fact that, as we saw in the previous section, the coercive power of the state must do more than merely seek the vindication of moral values: it must impact on the lives of citizens in a positive way. On the other hand, purely non-distinctive accounts fail to engage with the fact that the criminal law is concerned with the preservation of valuable autonomy, and therefore should speak a moral language of some kind; that, amongst the various functions of law, a morally-loaded regulatory tool has its place. ${ }^{56}$ In demonstrating how the PGA satisfies D2, this section will therefore show how it combines distinctive and nondistinctive elements.

In order to offer a defensible account of $\mathrm{D} 2$, the distinctive element of a theory of criminalization must have two components: first, it must possess a morally fine-grained approach to criminal wrongs; second, it must articulate a condemnation of those wrongs. In order to understand why a defensible account of D2 requires the first component, it is necessary to examine, and more importantly reject, a theory of criminalisation that eschews a fine-grained approach to criminal wrongs, the public law account of Malcolm Thorburn (the 'PLA'). ${ }^{57}$

The PLA's justification of criminalisation embodies a constitutional conception of the state's role with respect to the use of coercive and punitive force. Such an approach begins with a constitutional conception of the state, and then finds a role for the criminal law within that conception. ${ }^{58}$ It sees the state's fundamental responsibility as securing

55 As Simester and von Hirsch argue, where criminalisation is concerned ... "... [t]he truth is, we think, somewhere in between." (n 1) 4. See also T Hornle, 'Theories of Criminalization' (2016) Criminal Law and Philosophy 301, 302.

56 The expression 'a morally-loaded regulatory tool' is taken from Simester and von Hirsch Crimes, Harms, and Wrongs: On the Principles of Criminalisation (n 1) 11 .

57 Set out in various works, including 'Punishment and Public Authority' in $\mathrm{P}$ Asp, A Dubois-Pedain and M Ulvang (eds), Criminal Law and the Authority of the State (Bloomsbury 2017) 1; 'Constitutionalism and the Limits of the Criminal Law' in Duff, Farmer, Marshall, Renzo, and Tadros (eds), The Structures of Criminal Law (OUP 2011) 85; and 'Criminal Law as Public Law' in Duff and S Green (eds), Philosophical Foundations of Criminal Law (n 14) 21.

58 'Constitutionalism and the Limits of the Criminal Law' ibid 87-88. His argument is noted by Ashworth and L Zedner in 'Punishment Paradigms and the 


\section{PUBLIC GOODS AND CRIMINALISATION}

each citizen's equal freedom or autonomy, a responsibility that grounds its legitimacy. ${ }^{59}$ Thorburn explains:

Unlike any private actor, the state claims to speak in the name of everyone's claim of freedom equally. For this reason, the state is the unique instrumentality through which we may collectively ensure our freedom as independence. It speaks for us all together in setting down general laws that define the scope of everyone's freedom in the same way, but it does not speak for anyone in particular-and so, in that way, the state's actions are not to be confused with the partisan choices of some particular individuals. ... In short, we act together with others through the instrumentality of the state in order to secure for all of us the conditions of freedom as independence. ${ }^{60}$

In turn, the criminal law addresses violations of such individual freedom by others, that is to say it is concerned with identifying those who deliberately impose their preferences on others, thereby suppressing their freedom:

The ground of the liberal constitutional state's legitimacy is the simple fact that it — and it alone - can provide the conditions of freedom for all. On this account, the role of the criminal law is to identify when individuals are attempting to supplant the law's rules with their own preferred arrangements and to regulate the use of state power to resist such attempts. ${ }^{61}$

As such, the criminal law is conceived as maintaining, through its processes of condemnation and punishment, the equal freedom of all citizens. It is the characteristic of being a violation of the constitutional commitment to equal freedom that justifies the criminalisation of behaviour. Again, Thorburn explains:

... the criminal law's concern is with someone's efforts to undermine the whole system of equal freedom itself. ... Criminal wrongs are those that demonstrate a willingness on the part of the

Role of the Preventative State' in Simester, du Bois Pedain and Neuman (eds) Liberal Criminal Law Theory: Essays for Andreas von Hirsch (n 50) 3, 7-8.

59 Thorburn also refers to this equal freedom as 'jurisdiction': 'Criminal Law as Public Law' (n 57) especially 31.

60 Thorburn, 'Constitutionalism and the Limits of the Criminal Law' (n 57) 98.

61 'Constitutionalism and the Limits of the Criminal Law' (n 57) 88. 


\section{THE DENNING LAW JOURNAL}

offender to displace the legal rules themselves - they are concerned not merely with an injury to some specific rights claim, but to the very idea of living together under law rather than subject to the wishes of specific individuals. ${ }^{62}$

The above quotes reveal that the PLA, like the PGA, offers a theory of the criminal law embedded in, and thus justified by, a political theory of the state. ${ }^{63}$ As a justification for the use of the state's coercive power, there is no denying that the PLA's political approach has much to offer the impartial liberal. This is because its conception of the criminal wrong as the violation of equal freedom is embedded in what those of a Rawlsian inclination would consider a political value, rather than a comprehensive doctrine. This is then married to a Rawlsian justification of the criminal law's (coercive) power, the concrete realisation of that political value. At the same time, Thorburn claims to offer a distinctive account of the criminal law, and thereby respect D2: Thorburn states: "Criminal justice is not just a policy instrument for sharing the costs of bringing about a social good; rather it is an instrument for identifying wrongdoers and censuring them as such." ${ }^{64}$

Such an approach is distinctive to the extent that the failure to treat your fellow citizen as free and equal can attract a moral condemnation of a certain kind. As pointed out by Matravers: "To violate the demands of freedom and equality is, for the liberal, to do a substantive moral as well as political wrong." ${ }^{65}$ However, the violation of equality is too generic a conception of the criminal wrong to do justice to the various mala in se that populate the criminal calendar; in order to understand why, it is helpful again to quote Thorburn:

... what makes all [...] conduct wrongful for the purposes of the criminal law is that the offender has intentionally undermined the possibility of interacting with others as free choosers who are entitled to live under the terms of interaction set out by the law. $\mathrm{He}$ has done so by treating that person as a mere object who may

\footnotetext{
62 'Constitutionalism and the Limits of the Criminal Law" (n 57) 100.

63 Thorburn, 'Criminal Law as Public Law' (n 57) 24: “... I propose a different way of justifying the practices of the criminal justice system-a position I call a 'public law account' of criminal justice. I call it a 'public law' account because it conceives of the operations of the criminal justice system, insofar as they are legitimate, as concerned with the basic question of public law: when the use of state power is legitimate."

64 Thorburn, 'Constitutionalism and the Limits of the Criminal Law' (n 57) 97.

${ }^{65}$ Matravers, 'Political Neutrality and Punishment' (n 51) 221.
} 


\section{PUBLIC GOODS AND CRIMINALISATION}

be dealt with in whatever way he wishes. The wrong of rape-and of murder, assault, etc - is precisely the objectification of one person by another, but that objectification is of concern to the state because it is the state's job to ensure the survival of the system that makes it possible for us all to interact on terms that preserve the status of us all as free and equal moral agents. ${ }^{66}$

It is the fact that Thorburn equates the wrongs of murder, assault and rape that is precisely the weakness of his theory. Though these criminal wrongs share the moral failure articulated by Thorburn (and Matravers), their moral 'wrongness' is far richer and more varied than the mere violation of equality: murder entails the complete extinction of another person, rape involves a demeaning and arguably horrific violation of sexual integrity, ${ }^{67}$ assault is a violation of bodily integrity. Other criminal wrongs implicate further (in some cases central) human interests, for instance burglary is an invasion of the legally constructed but also morally meaningful interests in property and privacy. Because the PLA is blind to these differences, it has a flat and hence distorted sense of wrong done to the victim where these crimes are concerned. It is now appropriate to recall Duff's injunction above, that where crimes against individuals are concerned, "... what is central to the criminal wrongfulness of his action ... is the wrong done to his victim." 68 The PLA, with its exclusive concern with equality, is insufficiently fine-grained to acknowledge that wrongfulness properly.

It is worth noting that legal moralism, in all its forms, has no difficulty satisfying D2. This is because the fundamental rationale of all forms of legal moralism is the notion that a core, though not necessarily exclusive, aim of the criminal law should be the condemnation of criminal wrongs in their capacity as moral wrongs. The differences between the different forms of moralism concern which parts of morality they see as relevant to the criminalisation decision and the principles that limit the reach of their moralism. ${ }^{69}$ But what unites them is highly nuanced and developed concern with the moral nature of criminal wrongs, especially against individuals, and commitment to the notion that a deeper understanding of those moral wrongs represents a deeper understanding of how, and why, the criminal law condemns them. Thorburn might respond that this

\footnotetext{
66 Thorburn, 'Constitutionalism and the Limits of the Criminal Law' (n 57) 102.

67 Stanton-Ife, 'Horrific Crime' in Duff (eds), The Boundaries of the Criminal Law (OUP 2010) 138.

${ }^{68}$ Answering for Crime (n 23).

${ }^{69}$ Where those limits are concerned, for Gardner, it is harm; for Duff, it is the quality of publicness; finally, for Moore, it is certain restraining principles: see their works referred in this article.
} 


\section{THE DENNING LAW JOURNAL}

concern with moral wrongs is a weakness of legal moralism, not a strength. My concern here is not whether he is wrong or right, but simply that anyone who takes D2 seriously cannot support the PLA, given its flat and monochrome conception of criminal wrongs.

The PGA, however, shares legal moralism's concern with the finegrained moral wrong against the individual. This articulacy flows from the fact that, as demonstrated under D1, all public goods have moral character, a moral character derived from their concern with the preservation of valuable autonomy. This concern enables a fine-grained approach to such male in se wrongs as murder and rape. It was also demonstrated under D1 how this concern with valuable autonomy articulates the moral wrongs that occur in the context of public crimes and explains, in a nuanced fashion, the criminal law's concern with unjustified risk where its conception of recklessness is concerned. As such, the PGA, unlike the PLA, is sufficiently fine grained to articulate the moral nature of the various wrongs that populate the criminal calendar.

However, does the notion of maintaining a public good commit the PGA to a theory of the criminal law as a pure deterrent, offering only content independent (prudential) reasons, in the form of the fear of conviction and punishment, to observe its prohibitions? If so, despite often targeting moral wrongs as explained under D1, the PGA will still fail D2, as there will be no element of condemnation, simply the brute fact of coercion. This would mean the PGA would not articulate a condemnation of the moral wrongs it criminalises.

The PGA does not adopt such a reductive coercive conception of the criminal law, but instead integrates its concern with promoting public goods with the condemnation of the wrongs it criminalises. It does this by offering a dual 'moral-practical' account of the criminal law, an account that enables it to combine the distinctive and non-distinctive elements that, it was argued above, all theories of criminalization should possess. ${ }^{70}$ The article will now explain how.

Where condemnation is concerned, the PGA conceives of the criminal law as an official articulation of the moral reasons against the criminal

70 Hence Simester and von Hirsch's phrase to describe the criminal law: a 'morally-loaded regulatory tool' (n 56). As such it offers a hybrid (or mixed) account of the justification of criminalisation. For summaries of hybrid accounts, see Ashworth and Zedner, 'Punishment Paradigms and the Role of the Preventative State' (n 58) 3, 5, Thorburn, 'Punishment and Public Authority' (n 57) 15 and A Spena, 'Harmless Rapes: A False Problem for the Harm Principle' (2010) Diritto \& Questione Publicche 497, 506-507. For a defence of a mixed theory of criminalisation, as opposed to punishment, see Edwards and Simester, 'Prevention with a Moral Voice' (n 50). 


\section{PUBLIC GOODS AND CRIMINALISATION}

behaviour: consequently, conviction condemns those who were not persuaded by those moral reasons. This approach also accounts for the rules and principles of attribution, as such condemnation makes little sense without a concern with the questions of moral responsibility and culpability.

According to the PGA, however, the criminal law is also meant to impact on practical reason, with a view to preventing criminal behaviour. According to the PGA, it does this, first, by officially highlighting, and hence communicating, the moral wrongfulness, the mala, of the wrongs it criminalises. However, this moral appeal is reinforced by a prudential disincentive, in the form of the fear of conviction and sanction, for those who may not hear, or hear as loudly as they should, the criminal law's concern with the underlying first order reasons. The liberal view that the law should not concern itself with the moral character of citizens is therefore accorded some weight within this conception: if you comply with the requirements of the criminal law, the criminal law has no interest in why you have done so. The criminal law should be happy for us to comply for any reason, including the prudential reasons it supplies, because that is all that is required for creation and maintenance of public goods.

However, the criminal law does more than highlight, and supplement with prudential reasons, the moral reasons to not commit the wrongs it criminalises. It also offers moral and prudential reasons to exclude the reasons in favour of criminal wrongdoing. ${ }^{71}$ This is because, according to the PGA, excluding those reasons is necessary to ensure the behavioural consistency necessary to sustain public goods. ${ }^{72}$ This reason generates a moral obligation to pre-empt, namely that so doing provides the advantages made available to all by the creation and maintenance of

71 As such, it acts as an exclusionary reason, following Raz's conception of authority: see The Morality of Freedom (n 2) and Ethics in the Public Domain (n 3). See also 'The Problem of Authority: Revisiting the Service Conception' (2006) 90 Minnesota Law Review 1003, 1022, where Raz states that “... exclusionary reasons do not, of course, exclude relying on reasons for behaving in the same way as the directive requires ... [but] ... must ... override our inclination to follow reasons on the losing side of the argument. Hence the preemption excludes only reasons that conflict with the authority's directive." This must be correct: the criminal law should be entirely happy for us to refrain from acting upon the moral reasons against, say, murder or rape. But, contra Duff ( reasons alone.

72 This exclusionary power is subject to a limited number of exceptions, when the criminal law deems that acting on certain contrary reasons justifies committing the criminal wrong. The principles governing self-defence are an example. 


\section{THE DENNING LAW JOURNAL}

public goods, not least the highly valuable overarching benefits of public goods. But this is, once again, supplemented by a prudential incentive to exclude, the fear of conviction and sanction.

To summarise, the PGA offers a dual 'moral-practical' account of the criminal law. For those who already accord the proper moral weight to the criminal law's underlying moral concerns, its existence is, in fact if not in design, superfluous, though it serves as a vital indication that the state shares concerns with certain values and goals. But the criminal law is bilingual: to those who do not feel the rational pull of the underlying reasons, or does not feel that pull as strongly as they ought to, it offers content-independent prudential reasons to comply with its directives and exclude countervailing concerns.

However, a key challenge raised by Duff is the notion that deterrence, the supply of prudential reasons in the form of the fear of prosecution, conviction and punishment, bypasses the moral agency of the person coerced. As a result, its use does not treat the person with the respect he deserves, but rather as an entity to be manipulated by the fear of conviction and punishment. Duff believes this problem applies even when prudential reasons are combined with, or limited by concern with, the moral status of the agent. ${ }^{73}$ There are two elements to this criticism. First, that the supply of prudential reasons disrespects the moral agency of the individual coerced; second, that it treats the agent as a means to certain ends, those of individual and general deterrence.

These two elements constitute powerful objections to prudential reasons and reasons of space prevent this article from doing them justice. The second is the most powerful, and this article will have something to say about it in the next section. The first is addressed by the fact that the PGA does not conceive of the criminal law as an exercise in pure manipulation, but as a dual moral-practical form of persuasion. Moral agents acknowledge the role of prudential reason in practical reasoning and organisation, because of moral fallibility. ${ }^{74}$ But importantly too, those prudential reasons, and the exclusionary effect of criminal prohibitions, are offered in the name of the public goods: as such, desistance is demanded not without appeal to a moral reason of a kind and not without articulating a benefit to the person coerced. The prudential disincentive is therefore offered in the name of maintaining the valuable autonomy of all citizens, and so engages meaningfully with the moral agency of persons.

73 See Matravers, Justice and Punishment (n 53) 264. It is for this reason that Duff suggests conceiving of the criminal law completely differently, as an exercise in the communication of censure: (n 52).

${ }^{74}$ Matravers makes this very point: see The Jurisprudence of Antony Duff (n 42) 82. 


\section{PUBLIC GOODS AND CRIMINALISATION}

To express the idea another way, citizens engage with prudential reasons as part of an overall scheme of which they are the direct beneficiaries.

\section{THE PGA AND DESIDERATUM 3}

Desideratum 3 ('D3') acknowledges that criminalisation involves the exercise of power by the state and, therefore, that any theory of criminalisation should demonstrate a coherent understanding of how its conception of the criminal law coheres with a theoretical account of the legitimacy of that power. ${ }^{75}$ Some theories of criminalisation believe this relationship begins with, and is governed by, the political. This means the criminal law is justified in entirely political terms: consequently, the approach of such theories to D1 emerges from their conception of the state's nature and role. The PLA of Thorburn, described in the previous section, is an example. By way of contrast, the retributivist approach of Michael Moore begins life independently of political concerns, by offering an account of behaviour worthy of retributive punishment. It then only requires that the task of articulating that behavior, and punishing for its commission, is legitimately entrusted to the state, whatever form the state takes. ${ }^{76}$ As explained in the previous section, the PGA, like the PLA, adopts the former approach, with the result that its understanding of D1 emerges from, and is governed by, a political concern with the promotion of public goods. This section will explore in greater detail the implications of this approach.

75 Duff, Farmer, Marshall, Renzo and Tadros (eds), 'Introduction: Towards a Theory of Criminalization' in Criminalization: The Political Morality of the Criminal Law (n 22) 1, 5: "A theory of criminalization must ... include or depend on a political theory of state and society: it must be a theory of the role that criminal law should play within a particular kind of polity." See also Duff, 'Criminal Law Theories' in the Stanford Encyclopedia of Philosophy <https://plato.stanford.edu/entries/criminal-law/> accessed July 2017: "Philosophical theories of criminal law, whether analytical or normative, cannot subsist in isolation. For one thing, they cannot be wholly separate from other branches of philosophy. They must draw, most obviously, on political philosophy, since they must depend on some conception of the proper aims of the state and of the proper relationship between a state and its citizens."

76 Placing Blame (n 52). It is worth noting that Moore's legal moralism includes a number of principles that limit its concern with moral wrongs, most notably the presumption in favour of "the standing case for liberty" and epistemic modesty on behalf of legislators: see generally 'Liberty's Constraints' (n 43). See also Placing Blame (n 52) 75-80 and 'A Tale of Two Theories' (2009) 28 Criminal Justice Ethics 27, 32-33. 


\section{THE DENNING LAW JOURNAL}

Property offences and the public good of the property regime, as explained by Raz, illustrate the nature of this fundamentally political approach of the PGA:

Every person has ... an interest [in the protection of property rights by the criminal law] inasmuch as (1) every person may become a property owner; and (2) every person benefits from the fact that property rights are secure. These benefits take many forms. They are not easy to specify exhaustively. They come close to being the interest that all people have in living in a civil society. My right in my property is based on my interest in having that property. But the weight given to my interest, the degree of protection it deserves, and the form that protection should take is morally determined by considerations which transcend concern for my interest in itself. They reflect the interest of other people in the common good of respect for property. ${ }^{77}$

Raz here is referring to a notion that lies at the heart of the PGA and its approach to D3. This is the notion that the intrinsic value of public goods outlined at the outset of this article, the fact that they exist to benefit all, and create benefits that transcend the sum of individual and shared goods they embrace, should inform and limit the definition of criminal wrongs. The full implications of this observation can be drawn out by returning to the distinction between mala in se and mala prohibita crimes outlined in Section 3.

It was argued that the difference between these two types of crime is one of degree rather than one of kind. What this means is that, even with those crimes traditionally viewed as mala in se, there is an element of prohibita in the criminal law's definition of the wrong. According to the PGA, this is largely a consequence of the criminal law's political role as provider of public goods, and its concern with the overarching benefits of such goods. The explanatory and evaluative power of this approach can be illustrated with the following examples: crimes targeting driving with an excessive blood-alcohol concentration; the debate surrounding deceptions as to HIV-positive status within the crime of rape; finally, the reach of the defence of duress. These will be addressed in order.

The public good of a safe road traffic system, in its capacity as a framing good, plays a key role in providing many private and shared goods. Behaviour that poses an unacceptable risk to the safety of this system, such as excessive speed, driving without due care and attention and driving whilst intoxicated, is therefore a candidate for criminalisation.

${ }^{77}$ Raz, 'Rights and Politics' (n 5) 33. 


\section{PUBLIC GOODS AND CRIMINALISATION}

However, where road safety is concerned, the exact contours of any offences created, for example the speed limit on any given road, the standard of care for driving, and the legal level of blood-alcohol concentration, are not, and cannot be, articulated purely in terms of free standing morality, for example that it is wrong to put the lives of others at risk. The contours of these offences must also depend upon the overall objectives and overarching benefits of road use, as well as the costs of reducing risk and the collateral effect of criminalisation on other public goods. It is these factors that enable the relevant crimes to take their final form, and constitute the element of prohibita where such crimes are concerned.

Where legal levels of blood-alcohol concentration are concerned, this is illustrated by Anthony Bottom's analysis of Sir Peter North's proposal to lower the blood alcohol limit for the crime of driving with a bloodalcohol concentration above $80 \mathrm{mg} / 100 \mathrm{ml}^{78}$ As Bottoms points out, this proposal was rejected because it was decided that doing so would have very little impact on casualties, divert police resources away from the more serious cases, and even have a negative effect on commerce. This conclusion was reached despite a high degree of consensus that driving with any alcohol in the system is mala in se, that is to say morally wrong. It is the concern with public goods that explains why, nevertheless, the level was not lowered.

As pointed out in Section 3, whether the wrong of rape embraces all, or only some, frauds in the inducement leading to sexual intercourse is a controversy within morality ${ }^{79}$ Nevertheless, in order for the public good of sexual integrity to materialise, the criminal law must settle on which fraudulent inducements to include in its definition of the criminal wrong. According to the PGA, such a decision should be informed, in part, by the imperatives involved in maintaining the public goods affected by the decision to criminalise this or that fraud in the inducement. And so, whether misleading a sexual partner about HIV positive status, a fraud in the inducement, should negate consent within the context of sexual intercourse cannot be settled exclusively by moral concerns surrounding deceit; it should also engage with those moral and practical concerns raised by the maintenance of the public goods of public health and nondiscrimination. ${ }^{80}$

78 A Bottoms, 'Civil Peace and Criminalization' in Duff et al, Criminalisation: The Political Morality of the Criminal Law (n 22) 232, 261-264.

${ }^{79}$ See (n 20) and (n 21) and accompanying text.

${ }^{80}$ Matthew Weait has written extensively on this question: see, for example, Intimacy and Responsibility: The Criminalisation of HIV Transmission (Routledge Cavendish 2007). Gillick v West Norfolk and Wisbech Health 


\section{THE DENNING LAW JOURNAL}

The above has hopefully demonstrated how a concern with public goods has direct implications for the definition and reach of criminal wrongdoing. However, concern with the intrinsic value of public goods also has implications for the criminal law's rules and principles of attribution. The relationship between the defence of duress in English law and the public peace can be used to illustrate this.

The maintenance of the public peace demands a measure of consistent protection of physical and psychic autonomy, through both the deterrent effect of a police presence and the threat, and fact, of prosecution. The maintenance of this general climate of security for the benefit of all, and the overarching benefits it supplies, it is suggested, explain why the limits of the defence of duress should not be decided purely in terms of the moral culpability of the accused.

To illustrate, in the UK, the defence of duress is denied to those who knowingly or negligently expose themselves to threats of violence. ${ }^{81}$ If duress is conceived as an excuse, denying the defence to defendants on such grounds is defensible, as, arguably, they bear a measure of blame for subjecting themselves to the risk of the threat of violence. ${ }^{82}$ But the restriction also flows, at least in significant part, from a concern with maintaining the public peace. Lord Simon of Glaisdale acknowledged this interaction between culpability and maintaining the public peace where duress is concerned in DPP for Northern Ireland $v$ Lynch: ${ }^{83}$

A sane system of criminal justice does not permit a subject to set up a countervailing system of sanctions or by terrorism to confer criminal immunity on his gang. A humane system of criminal justice does not exact retribution from those who infringe the substantive provisions of its code under stresses greater than ordinary human nature can bear, nor attempt, by making an example of them, to deter those who in the nature of things are beyond deterrent. A sane and humane system of criminal justice is sufficiently flexible to reconcile such considerations, and to allow for all their infinite degrees of interaction. I have ventured to

Authority [1986] AC 112 is arguably an example of where concerns with the public good of public health helped generate a decision not to criminalise behaviour. In that case, a decision not to criminalise, under certain circumstances, the provision, by doctors, of contraceptive advice to those under 16 .

${ }^{81}$ Hasan [2005] UKHL 22.

${ }^{82}$ See Lord Bingham, ibid [38].

${ }^{83}$ [1975] AC 653. 


\section{PUBLIC GOODS AND CRIMINALISATION}

suggest that our own system of criminal justice is capable of such sanity and humanity... ${ }^{84}$

In the same vein, the Law Commission, in an exploration of the extension of the defence to murder, noted concerns expressed by the English judiciary that " $\ldots$ the members of a criminal gang might be capable, not only individually, but in collusion, of concocting a false defence of duress." $" 85$

Duff's concern, mentioned under D2, about using persons as a means to an end is most pertinent here. The fact that the reach of the defence of duress is not exclusively concerned with the moral culpability of the accused, but rather the goal of maintaining the public peace, means that, on occasion, a conviction involves, to a certain degree, sacrificing the individual to that goal. As a result, he is (partly) treated as a means to an end. Perhaps the only response to this is to accept that this is an inevitable feature of the criminal law, and that all that can be done is, as Lord Simon suggests, to balance the concern with the public peace with the concern with culpability. Perhaps some of this negative impact of the criminal law's concern with public goods can be addressed in the context of sentencing. However, any theory that attempts to purify the criminal law of this concern with public goods is likely to result in serious descriptive failures, undermine preventative goals and be overly idealistic, but the defence of these claims must be left to another occasion.

\section{THE PGA AND DESIDERATUM 4}

The above discussion reveals that PGA articulates the reach of the criminal law in ways that flow from its concern with the maintenance of public goods. In this final section, the article will explore Desideratum 4 ('D4'), that is, whether that concern distils criminal from non-criminal behaviour correctly. There are two facets to this question. First, D4 requires the articulation of principled limits to the reach of the criminal law. Second, respecting D4 means a theory of criminalisation should not exclude from criminalisation behaviour that ought to be included. This section will explore these two facets through an examination of two examples that test the plausibility of theories of criminalisation where they are concerned. It will begin with the question of principled limits.

The PGA has two features that ensure principled limits to the criminal law: first, the fact that criminalisation must promote valuable autonomy;

\footnotetext{
${ }^{84}$ Ibid 696.

${ }^{85}$ Law Commission, Legislating the Criminal Code: Offences against the Person and General Principles (Law Com No 218 Cm2370, 1993) [33.2].
} 


\section{THE DENNING LAW JOURNAL}

second, the characteristic of public goods as non-excludable and nonrivalrous, meaning the autonomy they provide must be available to all citizens equally. ${ }^{86}$ This can be illustrated by contrasting offences against the person with the notion of criminalising homosexual sex.

The ban on interpersonal violence provided by the various offences against the person in the criminal calendar enables each citizen to exercise the valuable autonomy that flows from freedom from physical and psychic violence. This is achieved by criminalising, and hence systematically prohibiting, behaviour that prevents or hinders the exercise of that valuable autonomy; in other words, providing protection to all from violence helps create the non-excludable, and non-competitive good, known as the public peace. By way of contrast, banning homosexual sex does not augment the autonomy of citizens in any way. This is because such a ban does not target behaviour by any given citizen that impinges on the exercise of sexual integrity by another. Citizens do have an interest in their sexual autonomy and the protection of their sexual choices and inclinations, whatever they may be, and so behaviour that infringes on that sexual autonomy, such as sexual assault and rape, are legitimately criminalised according to the PGA. By way of contrast, prohibitions that seek to prevent citizens from exercising that valuable autonomy are illegitimate according to the PGA. According to the PGA, criminal coercion is used only to promote valuable autonomy, not suppress valuable autonomy, in order to create a non-excludable good.

Some might suggest that homosexual sex is not a form of valuable autonomy, on grounds of immorality. However, even if this premise were true (a position rejected by this article), the PGA's exclusive interest in promoting valuable autonomy, as opposed to suppressing valueless autonomy, would mean that any supposed immorality of such behaviour is irrelevant to its criminalisation according to the PGA. The PGA does not permit the criminalisation of valueless autonomy merely by dint of it being valueless: that behaviour must negate the valuable autonomy of others, directly or indirectly, thereby undermining a public good. Homosexual sex does not do that.

Attention can now turn to the second facet, which is whether the PGA excludes from criminalisation behaviour that ought to be criminalised. Its plausibility here can be interrogated by examining its approach to the criminalisation of non-consensual medical treatment that heals and, therefore, arguably does no harm to that patient. This is the case of wrongdoing that is beneficial to the victim.

\footnotetext{
86 This does allow for some exclusions of a non-arbitrary kind, such as children from the shared good of contract or the individual good of voting, see text of (n 4).
} 


\section{PUBLIC GOODS AND CRIMINALISATION}

Imagine a doctor who ignores the refusal of a patient for a blood transfusion, saving the patient's life. Given the non-consensual invasion of bodily autonomy, this example is intuitively one of criminal activity, in the form of an offence against the person. It is used to challenge those theorists who conceive of harm, in the form of forward-looking losses of autonomy, as a necessary condition of criminalisation. ${ }^{87}$ Given the forward-looking autonomy enhancing, as opposed to negating, effect of such treatment, it would seem the treatment is harmless, and therefore cannot be criminalised according to those theorists. However, whilst this is a powerful challenge to such theorists, it does not undermine the PGA.

First, the fact that the treatment heals does not mean the autonomy exercised in refusing is valueless: it may be the product, say, of religious conviction, and the ability to put into practice one's religious beliefs is valuable activity. So, the criminalisation of such treatment still promotes valuable autonomy. But, for the sake of argument, let us imagine that the refusal of treatment is worthless, for example based on racial prejudice against the treating doctor. If the PGA requires that criminal prohibitions should only target behaviour that negates the exercise of valuable autonomy in others, it seems that such a prohibition is not justified by its lights, as it only protects the exercise of valueless autonomy by the person refusing treatment. This is a counter-intuitive result and, if required by the PGA, would undermine its plausibility.

The PGA's approach to this question takes a more practical turn at this point. Offences against the person increase the valuable autonomy of persons, but in offering blanket protection, doubtless valueless autonomy is protected by them as well. However, the PGA considers it impractical to allow or encourage citizens to decide for themselves when their victim is exercising valuable or valueless autonomy, either empirically (have they assessed the situation correctly?) or as a matter of moral judgment (is the autonomy indeed valueless?). It is far safer for the overall promotion of valuable autonomy, including the valuable autonomy protected by the public peace, that the criminal law does not allow citizens to so

\footnotetext{
87 Those who subscribe to the forward-looking conception of harm as a necessary condition of criminalisation include Gardner: see Offences and Defences (n 1): the notion that "... life-prospects are being affected adversely ..." 244; Simester and von Hirsch Crimes Harms and Wrongs, Ch 3 'Crossing the Harm Threshold' (n 1) and 'On the Legitimate Objectives of Criminalisation' (n 41) 378. Raz also subscribes to a forward-looking conception of harm: see The Morality of Freedom (n 2) 413-414 and 416. This might be labelled the 'prospect harm' conception, to use Stanton-Ife's term when summarising the position of such theorists: see his 'Horrific Crime' in Duff, Farmer, Marshall, Renzo and Tadros (eds), The Boundaries of the Criminal Law (n 67) 129, 159.
} 
discriminate, as the potential for error by those persons is very great indeed.

Theorists who criticise the harm principle for failing to account for the criminalising of the doctor's behaviour argue that when wrongdoing consists in the violation of another's rights to personal autonomy, that wrongfulness alone is enough to justify criminalisation, and so the case should be accounted for on those grounds. ${ }^{88}$ Such an approach risks missing the point that the harm principle addresses a central concern of criminalisation: the need to justify the fact that the criminal law is a creature of the state. ${ }^{89}$ All theories of criminalisation should therefore offer such a justification: it is not enough simply to declare violations of autonomy worthy of criminalisation upon the basis of wrongfulness alone. John Gardner has addressed this need in the context of the wrong of rape:

... the would-be rapist is a would-be wrongdoer. This already picks him out as a suitable person to be threatened with punishment (coerced). It is not the job of the harm principle to pick him out again. The job of the harm principle is to regulate the wider purposes of the law that does the threatening. This law, and indeed every coercive law, must have and fulfil a harm-prevention purpose. The prevention of offence, distress, pain, vice, or indeed further wrongdoing is not sufficient warrant for coercion by law unless by such coercion the law also prevents harm. ${ }^{90}$

The question boils down to finding the correct principle to justify state intervention. For Gardner and others, it is harm; for Thorburn, it is the state's responsibility to secure the equal freedom of all citizens; for Duff, it is the vindication of moral values that concern the polity as a whole; ${ }^{91}$

88 H Stewart, 'The Limits of the Harm Principle' (2010) Criminal Law and Philosophy 17, 33, where Stewart calls such violations 'juridical wrongs'. He is not the only theorist to suggest that the presence of juridical wrongs is sufficient to justify criminalisation: see Stanton-Ife, 'Horrific Crime' ibid 161. Alternatively, fidelity to the harm principle where juridical wrongs are concerned might be maintained by conceiving of the wrong itself as also a harm, though not of the 'prospect' kind: see Stanton-Ife, 'Horrific Crime' ibid 159-162 and A Spena, 'Harmless Rapes: A False Problem for the Harm Principle' (2010) Diritto \& Questione Publicche 497, especially 513 onwards.

89 As pointed out by JG Murphy in 'Retributivism, Moral Education and the Liberal State' (1985) 4 Criminal Justice Ethics 3, 4.

${ }^{90}$ Gardner, Offences and Defences (n 1) 243.

${ }^{91}$ It should be noted that Duff's normative vision of the criminal law does not see it as a coercive practice. 


\section{PUBLIC GOODS AND CRIMINALISATION}

and for Moore, it is the state's duty to impose just retribution. For the PGA, as this article has argued, it is the maintenance of public goods. ${ }^{92}$

The nature of the PGA is further explicated by offering some brief observations on how the PGA might approach the issues concerning sadomasochism raised by the decision in $R v$ Brown..$^{93}$ The accused in that case consented to the activities in question, and so were exercising their sexual autonomy. As a result, the criminalisation of their behavior would not appear justified under the PGA, since it arguably targets activity on the basis of its supposed immorality, as opposed to targeting behaviour that reduces the exercise of valuable autonomy in others. Can the criminalisation of the behaviour in Brown nevertheless be justified under the PGA? It is suggested that if the criminalisation of such behaviour is to be so justified, it should be in the form of public crime. If its criminalisation promotes a public good, say a general commitment to noncruelty or the maintenance of public health and so, directly or indirectly, increases the valuable autonomy of individuals, then that arguably presents a (prima facie) case for so doing. But such an objective must be carefully balanced, in an informed way, against the value of protecting and promoting sexual integrity, both where the individual and the public good are concerned. It is only after such an analysis that, according to the PGA, the decision to criminalise can be reached. Much depends, it may be supposed, on the level of violence intended by the participants.

Finally, it is suggested that a concern with public goods allows us to understand why certain moral wrongs conventionally seen as beyond the reach of criminalisation, such as adultery and lying to friends, are legitimately seen that way. It is only when moral wrongdoing impacts on a public good that it is potentially worthy of criminalisation. This is why romantic infidelity and betrayals within friendship are not worthy of criminalization under the PGA, because their occurrence does not impact on any public good. Indeed, there is a public good in the general availability to form and manage our own romantic and other kinds of

\footnotetext{
92 For Raz, the impact on valuable autonomy constitutes harm, of the prospect kind (see n 87): see The Morality of Freedom (n 2) 417 and 426. The PGA therefore has much in common with those theorists who support the harm principle as a necessary condition of criminalisation. However, though this claim cannot be defended here, the PGA as this article conceives believes that valuable autonomy and public goods can be undermined other than through prospect harm. Also, in contrast to harm moralists such as Gardner, the PGA fuses its concern with moral wrongs with its political conception of the criminal law, as opposed to seeing the prevention of harm as an independent political concern of the criminal law once a (non-political) moral wrong has been established.

93 [1994] 1 AC 212.
} 
relationships. If the criminal law was to threaten conviction for the various forms of betrayal that can occur in such relationships, it would often remove the element of sincerity that is key to the existence of the shared goods of marriage and friendship and the public goods of which they are part. ${ }^{94}$

\section{CONCLUSION}

As stated at the outset of this article, for a theory of criminalisation to draw on the notion of public goods is not new. The fundamental aim of this article was therefore to explore and defend, in greater depth than has occurred previously, the implications of a theory of criminalisation embedded in the notion of public goods. The use of the four desiderata was designed to tease out the merits of such a theory, in the most salient and explicit way possible. All of this has been done with the hope of stimulating further analysis of what this article believes is an extremely promising theory of criminalisation.

${ }^{94}$ For a similar point, see Horder, Ashworth's Principles of Criminal Law, (n 1) 54. 